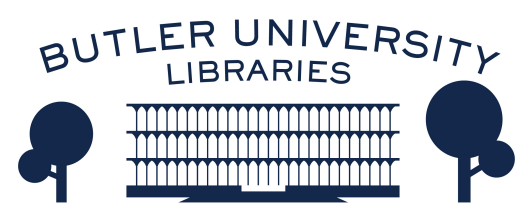

Journal of Hindu-Christian Studies

Volume 18

Article 7

January 2005

\title{
Can Women Be Priests? Brief Notes Toward an Argument From the Ancient Hindu World
}

Laurie L. Patton

Follow this and additional works at: https://digitalcommons.butler.edu/jhcs

Part of the Religion Commons

\section{Recommended Citation}

Patton, Laurie L. (2005) "Can Women Be Priests? Brief Notes Toward an Argument From the Ancient Hindu World," Journal of Hindu-Christian Studies: Vol. 18, Article 7.

Available at: https://doi.org/10.7825/2164-6279.1340

The Journal of Hindu-Christian Studies is a publication of the Society for Hindu-Christian Studies. The digital version is made available by Digital Commons @ Butler University. For questions about the Journal or the Society, please contact cbauman@butler.edu. For more information about Digital Commons @ Butler University, please contact digitalscholarship@butler.edu. 


\title{
Can Women Be Priests? Brief Notes Toward an Argument From the Ancient Hindu World
}

\author{
Laurie L. Patton \\ Emory University
}

CAN women be priests? If the word priest means ritually authoritative, the answer from the early Indian world is resolutely "yes." I want to begin by stating straightforwardly that in various periods of Indian history women have acted in ritually authoritative ways. And in my own experience of contemporary Maharashtra, while male priesthood might remain a cultural norm, one can find exceptions everywhere. While Vasudha Narayanan has written about most of these practices elsewhere on this issue, I would add that today in Maharashtra, women are training in large numbers to be ritual specialists, even purohits, because of the shortage of men. Moreover, it is reported that they are trusted more than the men to charge reasonable fees and to show up when needed. Their repertoire of Vedic verses tends to be thinner--usually consisting of some Gita, the Gayatri, the Purusha Sukta (RV 10.90), the wedding hymn (RV 10.18), and perhaps some sections of Ramayana. While time prevents me from delving deeply into the contemporary issues and struggles for these women, nonetheless recent field work in this area suggests that women's expertise and popularity is fast expanding. ${ }^{1}$ Women ritual specialists, trained by Upasini Baba in his ashram at Sakori, Maharashtra, beginning in the 1930's, have weathered challenges and cultural debates, and gone on to thrive in the 1980 's and 1990's. And today, the actual number of stri-purohits, or women ritual specialists, is also growing rapidly. According to one report by V.L. Manjul, women ritual specialists now outnumber their male counterparts in certain neighborhoods in Pune. And social acceptance locally is at an all-time high.

But what of ancient models and the possible contemporary uses of those models? Recent scholarship of Mary McGee, Stephanie Jamison, Katherine Young, and myself among others ${ }^{2}$ have shown evidence for women reciting mantras in certain shrauta sacrifices; women reciting

Laurie L. Patton is Winship Distinguished Research Professor and Chairperson of the Department of Religion, Emory University. Her scholarly interests are in the interpretation of early Indian ritual and narrative, comparative mythology, literary theory in the study of religion, and women and Hinduism in contemporary India. She has recently returned from India where she worked as a Fulbright scholar, completing research for her forthcoming book, Grandmother Language: Women and Sanskrit in Maharashtra and Beyond. Her translation of the Bhagavad Gita is forthcoming from Penguin Press Classics Series. She is the author or editor of seven books: Authority, Anxiety, and Canon: Essays in Vedic Interpretation (ed., 1994); Myth as Argument: The Brhaddevata as Canonical Commentary (author, 1996); Myth and Method (ed., with Wendy Doniger, 1996); Jewels of Authority; Women and Text in the Hindu Tradition (ed., 2002); Bringing the Gods to Mind: Mantra and Poetry in Early Indian Sacrifice (author, 2004); and The Aryan Controversy: History, Evidence and Inference (ed., with Edwin Bryant, 2005). Her book of poetry, Fire's Goal: Poems from a Hindu Year, was published by White Clouds Press in 2003 . 
mantras in the home in grihya rites; women being ritually authoritative in the village and presiding over marriage rites; and women undergoing the upanayana ritual in order to be introduced to Vedic study. Moreover, women pounded rice, cleaned the animals, laid the bricks, and cooked in preparation for the sacrificial performances, just as they do in sacrificial revivals today. And, as Frank Clooney and Mary McGee have also pointed out, women have adhikara, or ritual authority $^{3}$. The ritual philosopher of Mimamsa, Jaimini, resolutely makes the argument against the purvapakshin, or "philosophical opponent" who excludes women from sacrificing: Jaimini argues that a woman's being "sold" in marriage is not an essential property of who they are, and thus this does not disable her from sacrificing (JM 6.1.10.-15).

The key to the Mimamsa discussion is that women must remain married and property owners in order to sacrifice in the Shrauta world. The adhikara of a woman is clear in that she must have a husband and they must sacrifice with both. She is not independently qualified to sacrifice. However, both are needed to perform the sacrifice and the rituals fruits accrue to both. As Taittiriya Brahmana states, "He who has no wife has no sacrifice" (2.2.2.6) Thus, it is important to remember that either a single man or a single woman would fail if they sacrificed alone.

There are, however, also some possibilities for women performing independent shrauta sutra sacrifices. One text (8.23). describes a widow being able to offer to fires that have been kindled with her husband. These are indeed grhya rites, but still, as in most grhya rites, they are shrauta analogues. These rites constitute what Jamison calls a "shadow shrauta life."4 Gautama Dharma Sutra, which seems to be the most liberal of the Sutras, allows a man to designate a daughter as a ritual specialist (28.15) in the case of the absence of a son. It is important to note here that the ceasing of marriage involves the ceasing of adhikara for both men and women. A man becomes a renunciant and must no longer maintain the fires; this is clear from almost all the early shastric texts. Thus, priesthood per se, defined as the ability to sacrifice, is not a permanent religious authority for either men or women, contingent as it is upon the marital state.

Let me turn now to putting on the lens of a contemporary Mimamsa feminist thinker and see whether one can imagine other possibilities for women to be sacrificing priests according to Mimamsa rules. There are, I think, important arguments and speculations that might be considered in favor of women priests, if we posit that the proper Mimamsa (and therefore Vaidika) definition of marriage is the ability to reproduce.

Let us turn to the first issue of marriage and reproductive technology. Manava Shrauta Sutra (6.23.10), the wedding hymn RV 10.85, Chandogya Upanishad 14, Ashvalayana Grihya Sutra 1.7 and many other texts, state that the purpose--the artha if you will--of marriage is indeed procreation. If that is the case, and marriages could be dissolved on the basis of lack of children--then what happens to such rules when procreation does not depend on the biological technology of man and woman joining in sexual union? Fertility in the twenty first century is not necessarily linked to such a union, but rather to the presence of a sperm and egg. Thus, if a woman was without a husband in the twenty-first century, but still had her husband's sperm, she would technically still have adhikara.

Second, as Mimamsa thinkers, we might also consider the case of marital separation and its implication for women performing sacrifice. If their husbands had left them, women were allowed to wait seven years before they were allowed to remarry (Gautama Dharma Sutra 18.15). Then the question becomes, if she had access to reproductive technology even in the absence of a husband who was still alive, could a woman still sacrifice even if her husband were not physically present? The texts could not have anticipated this situation, and therefore did not address it. 
But we could possibly answer in the affirmative. This intriguing area needs further investigation.

Third, there is also the model of reproduction as it is practiced in svarga by the gods. While stories of the gods activities are defined as "arthavada" at best--praise to be attached to codana, or ritual injunction, they still have exhortatory force. And many Vedic stories, such as that of Martanda or Vivasvat, actually discuss reproduction in a way that does not involve actual copulation, as is also so common in later texts. Technically, as is the case in the twenty-first century, if humans have attained methods of reproduction previously available only to the gods, there is no reason why women or men should be disallowed from sacrificing. Again, this is another area for exploration.

Finally, there is the issue of the sages as mediators of the eternally present Veda. Several women seers, such as Lopamudra (RV 1.179), actually are speakers of Vedic verses with optative force (v. 6), and would therefore qualify as injunctive, and direct statements of dharma. While according to Mimamsa views; such women are only agents for an authorless text, they still remain as direct mediators of dharma, and therefore have adhikara to inquire into the nature of dharma (dharmajijnasa), as is so crucial to the conduct of Mimamsa philosophy. These women's injunctive statements become models for ritual experts tying to understand dharma as it is stated in the Veda. (I might add here that Devi Tai, one of the oldest women priests at the Upasini Baba ashram, also did an informal study of women who spoke in the Veda; a Mimamsa thinker would want to divide those speech acts into what was authoritative as codana and what was not--but the point that women speak Veda is understood by all. $)^{5}$

I might add one final, and to my mind, most important preliminary reflection: In addition to these ritual speculations and proto-arguments, as contemporary Mimamsa thinkers, I think we can also make a small intellectual path to include women in a more basic way in the philosophy--to open up a space for women's ritual expertise not as exceptions but as crucial to the entire ritual enterprise. The Mimamsa is resolutely clear that one must attempt to connect this world (laukika) and the world of the idea (vaidika). Sacrifice must always be connected with the experience of everyday life. Sacrifice will always be full of meaning--even beyond its ritual meaning, it must be full of what Francis D'Sa calls "significance." Thus sacrificial action makes daily life and duties meaningful. And, while Clooney has recently given us a subtler view of the role of deities, ${ }^{6}$ it still is the case that Mimamsa's understanding of deities was subordinate to its understanding of svarga, or priti--the center of the sacrificial wheel, as D'Sa puts it.

D'Sa examines priti in an intriguing way. ${ }^{7}$ According to the commentator Shabara, priti is a specific instance of the reality of purushartha, or the aims of humans. "That in which humans find priti, that significant thing (padartha)--which when accomplished gives rise to priti, that significant thing is known as the purushartha. Why is this the case? The innate longing for it is caused by the artha; such an innate longing is due only to artha." As D'Sa looks at it, whenever a person acts, the innate desire for "that significant thing," which is the purpose of humans, is at work. The object which brings about priti attracts the subject who longs for it, and the subject who longs for it is also attracted to any object who seems to produce it. In our being and in all our activities such ultimate aim is at work.

There is much else to discuss here, but most importantly I want to argue that priti should be seen as synonymous with svarga, as Shabara also argues. (Shabara Bhashya 5-9; 4.3.7.15.) Svarga is priti, and everyone longs for priti. However, svarga cannot be identified with any particular object--hence sacrifices which do not mention a phala, or result, such as the Visvajit sacrifice, are prompted by. the innate desire for svarga. Hence all sacrifices produce the one result: svarga. As $\mathrm{D}^{\prime} \mathrm{Sa}$ argues, such a desire is an intuitive 
instinct among people. Thus, as Shabara states somewhat humorously, "Devadatta has built a park; svarga is the result; Devadatta has dug a tank; svarga is the result." (Sbh 1.2.56.11-16; 4.3.7.16.)

I go into these details for several reasons. Let me begin with purushartha. Under the category of priti, that specific instance of purushartha, there is technically no reason to exclude the category of women's happiness, and women's flourishing, as one aspect of such general happiness. To be sure, one of the basic building blocks of Mimamsa is that the relationship between a word and its object or ultimate meaning is not created, nor conventional, but existent beyond the human (apaurusheya) and beyond origin in time (nitya or autpatti). However, as Othmar Gachter writes of Mimamsic interpretation, the presence of an artha, an object or ultimate meaning of a sacrifice needs to be integrated into the reader's present situation and experience. As such, Mimamsa hermeneutics cannot reproduce the original intention of a text, nor can it allow for an imposition of meaning from several millenia later. Rather, it is a participation in reality here and now, and it has become clear over the centuries that such a reality involves the well being of women. As Gachter goes on, jijnasa, or the desire to know, requires an openness which neither distorts the meaning of the text nor distorts the intention of the reader or listener. What is to be understood in a text is accessible in a new perspective or dimension. ${ }^{8}$ A concern for women's flourishing is present in many Vedic statements (see RV 5.78, for instance, which is a hymn concerning safe childbirth, and used as such in the later Vedic texts concerning mantric application.) ${ }^{9}$.

What is more, if we take D'Sa's treatment of this idea of priti as "ultimate significance," which can only be translated into committed action (that is the yajna, in Vedic times), then one would actually be able to say that such sacrificial action on behalf of women is a crucial element in that larger understanding of significance. If one looks at the traditional indicators for such happiness, such as abundance, long life, or offspring, then one can also argue that women's flourishing in all of these areas is crucial for that larger, generalizable purushartha. It cannot be reduced to this artha, but it can be made a central element of it, such as water or oxygen. In fact, one could also argue that rites which are organized for women's flourishing could be viewed as nitya, and not kama rites, because they are undertaken without specific desire but for the common good.

I want to stress here that this larger philosophical point is different than saying that women's presence is essential for their husbands to sacrifice, as we have already established, or reminded ourselves, in the last decade of scholarship. While this historical point is crucial, it is different than marking, or including, the well-being of women as part of that essential longing for priti which informs all of Mimamsa ritual. A related point can and should be made about svarga. As Clooney points out, Jaimini says very little about svarga, despite its being the central motivation for so much of Vedic action. ${ }^{10}$ But we might well understand svarga by its larger compound of svargaloka, the world of svarga, which is so common in Vedic texts. And if we do understand it this way, we also can benefit from taking the view that Jan Gonda does of loka-not exactly of a space, but of something expansive, a place to be free in or to run around in. ${ }^{11}$ As he notes, the opposite of loka was the constriction of space, and its synonyms were words like urn, urvi, and so on, meaning "wide." This would mean that part of svarga is the freedom to expand, to move into different arenas, and that would include both men and women doing more expansive things in that expanded realm. Gonda goes on to argue even more provocatively, and I think persuasively, that loka is as much a "transformed" and "widened" mental state that can come about as a result of an action. And if this is the case, then we can read Mimamsa in a very different and intriguing way--in which sacrificial action results in a transformed 
mental state which may or may not be directly evident.

If such an indication about purushartha and svargaloka is established, then a whole series of other possibilities opens up for women and ritual participation through Mimamsa. This possibility is not because there are ritual prohibitions for women that are removed, but rather because the very nature of dharmic action, and sacrificial action (subordinate to priti as Shabara indicates), must include women's actions and women's well being as part of their definition. And if this is so, then women's ritual participation and leadership may well be crucial for women's significance, or artha, in the larger sense that D'Sa so helpfully gives us. And women ritual participation, as the expanded action that svargaloka would imply, would be one among many forms of expanded activity of that loka, or space.

The points above are meant as philosophical "beginnings" and in no way a thoroughly worked out system. They are meant to be thought-provoking and suggestive.

\section{Notes}

${ }^{1}$ Personal communication, V. L. Manjul and Devi Tai, Upasani Kanya Kunari Sthan, August 2004. Also see V.L. Manjul, "Shirdi-Sakuri Don Upasana Kshetre" in Sri Sadguru Sairkrpa Dassara-Diwali Issue, 2003, 64-68; "Hitherto Forbidden Realm" in Manushi pp.38-39. Also see Manjiri Damle, "Women Priests Win Hearts for Dedication Times of India" 11/29, 1997; and "Maidens Mastering Man's Mantra-Veda" Sunday Herald Spectrum 11.24 June 4, 2004; and "Starting Vedic Studies" in Hinduism Today (Oct/Nov/Dec 2002): 59

${ }^{2}$ For a start, see Mary McGee, "Ritual Rights: Gender Implications of Adhikara"; Laurie Patton, "Mantras and Miscarriage: Controlling Birth in the Late Vedic Period"; Stephanie Jamison, "Giver or Given? Some Marriages in Kalidasa"; and Katherine Young, "Om, The Vedas. And the Status of Women with Special Reference to Shrivaishnavism"; all in Jewels of Authority: Women and Textual Tradition in Hindu India, Edited by Laurie Patton (New
York: Oxford University Press, 2002). Also see Jamison, Sacrificed Wife/Sacrificer's Wife: Women, Ritual and Hospitality in Ancient India (New York: Oxford University Press, 1996); Schmidt, Hans-Peter, Some Women's Rights and Rites in the Veda (Pune: Bhandarkar Oriental Research Institute 1987).

${ }^{3}$ See the larger discussion, in "Ritual Rights: The Gender Implications of Adhikara," in Jewels of Authority, pp.42-3. Mcgee's discussion informs the next two paragraphs.

${ }^{4}$ Jamison, Sacrificed Wife, pp. 36-7.

${ }^{5}$ Personal interview with Devi Tai, Sakori Ashram, Juily 13, 2004.

${ }^{6}$ Francis X. Clooney, "What's a God? The quest for the right understanding of devata in Brahmanical ritual theory (mimamsa)" International Journal of Hindu Studies 1.2 (1997):337-85. .

${ }^{7}$ Francis X. D'Sa, Sabdapramanyam in Sabara and Kumarila: Towards a Study of the Mimamsa Experience of Language. (New Delhi: Motilal Banarsidass, 2004); see especially pp. 28-9.

${ }^{8}$ Othmar Gachter, Hermeneutics and Language in Purva Mimamsa: A Study in Shabara Bhashya (Delhi: Motilal Banarsidass, 1990), pp. 101-02.

${ }^{9}$ See a fuller discussion of the interpretive possibilities using this hymn RV 5.78 as a hymn against female infanticide, in "Mantras and Miscarriage."

${ }^{10}$ Clooney, "Gods," p. 389.

${ }^{11 .}$ Jan Gonda, Loka: World and Heaven in the $V e d a$, Verhandleingen der Koninklijke

Nederlandse Akademie van Wetenschappen, (North Holland, Amsterdam: Afd. Letterkunde, 1966/67)). Niewe reeks, d.73, n.1. 